\title{
KEPUASAN PELAYANAN PUBLIK DI KECAMATAN KEDUNGKANDANG KOTA MALANG
}

\author{
Oleh: \\ Aisyah Anggita Rosmitha \\ Mahasiswa Pascasarjana Universitas Muhammadiyah Malang \\ E-mail/No. Hp: aisyah_ar@yahoo.co.id/-
}

\begin{abstract}
The research purpose is to find out about people satisfaction level to public service at Kedungkandang sub-district Malang city. Analysis technique used in this research is tabulation analysis and public satisfaction Index or analysis of all research data result. For the ten indicators in tabulation equation analysis, there found nine indicator stated that public satisfaction is quite enough, while one indicator stated that public satisfaction of public service is very satisfied. While for public satisfaction Index analysis, there found overall index value found index number 66.12, so that public satisfaction in Kedungkandang subdistrict viewed from all indicators in public service stated quite satisfied but close to satisfaction index less satisfied because of convection result of public satisfaction Index value.
\end{abstract}

Keywords: public service, public satisfaction index analysis, and Malang

\begin{abstract}
Abstrak
Tujuan penelitian ini adalah untuk mengetahui tingkat kepuasan masyarakat terhadap pelayanan publik di Kecamatan Kedungkandang Kota Malang. Teknik analisis yang digunakan dalam penelitian ini adalah analisis tabulasi dan Indeks kepuasan publik atau analisis dari semua data hasil penelitian. Selama sepuluh indikator dalam analisis persamaan tabulasi, ada ditemukan sembilan indikator menyatakan bahwa kepuasan publik sudah cukup, sementara satu indikator menyatakan bahwa kepuasan publik pelayanan publik sangat puas. Sedangkan untuk analisis Indeks kepuasan publik, ada menemukan nilai indeks keseluruhan menemukan nomor indeks 66,12, sehingga kepuasan publik di Kecamatan Kedungkandang dilihat dari semua indikator dalam pelayanan publik menyatakan cukup puas tetapi dekat dengan indeks kepuasan kurang puas karena hasil konveksi kepuasan publik nilai indeks.
\end{abstract}

Kata Kunci: pelayanan publik, analisis indeks kepuasan masyarakat, dan Malang

\section{PENDAHULUAN}

Undang-undang Dasar 1945

telah mengamanatkan, bahwa Negara

wajib melayani setiap warga negara

dan penduduk untuk memenuhi pelayanan umum dan peningkatan kesejahteraan masyarakat. Tujuan otonomi daerah yaitu meningkatkan kesejahteraan masyarakat, meningkatkan pelayanan umum dan

kebutuhan dasarnya dalam rangka 
meningkatkan daya saing daerah (UU nomer 32 tahun 2004, pasal 2 ayat 3).

Kegiatan pelayanan publik adalah segala kegiatan pelayanan yang dilaksanakan oleh penyelenggara pelayanan publik sebagai upaya pemenuhan kebutuhan penerima pelayanan maupun pelaksanaan ketentuan peraturan perundang-undangan. (Keputusan Menteri Pendayagunaan Aparatur Negara (MenPan) nomer 63/KEP/M.PAN/7/2003). Kegiatan memberi adalah suatu sikap untuk lebih mengutamakan kepentingan orang lain diatas segalanya termasuk dirinya sendiri. Suatu sikap untuk membuat orang lain terhormat dan dihargai. Sikap memberi tidaklah harus dianggap sebagai suatu sikap merendahkan diri sendiri melainkan sikap yang terpuji dan agung yang menunjukkan ketinggian nilai pada seseorang. Dalam kegiatan pelayanan publik, semangat memberikan yang terbaik bagi orang lain yang dilayani haruslah dipahami sebagai suatu sikap yang muncul dari sebuah kesadaran akan nilai-nilai tersebut. Sehingga melayani kemudian tidaklah dipahami semata sebuah kegiatan untuk memenuhi tanggung jawab formal seorang petugas terhadap mereka yang dilayani.

Kota Malang adalah salah satu kota di Provinsi Jawa Timur yang berada di dataran tinggi cukup sejuk terletak pada $90 \mathrm{~km}$ sebelah selatan kota surabaya dan wilayahnya di kelilingi oleh Kabupaten Malang. Malang merupakan kota terbesar kedua di utara timur dan dikenal dengan julukan kota pelajar. Kota Malang terdiri atas 5 (lima) Kecamatan, yaitu Kecamatan Kedung kandang, Kecamatan Sukun, Kecamatan Klojen, Kecamatan Blimbing dan Kecamatan Lowokwaru. Jumlah penduduk Kota Malang 768.000 (data sensus statistik 2008), dengan tingkat pertumbuhan $3,9 \%$ pertahun. Sebagian besar adalah suku jawa, serta sejumlah suku-suku minoritas Madura, Arab dan Tionghoa.

Di Kota Malang terdapat banyak pelayanan jasa publik yang disediakan. Salah satunya pelayanan jasa publik Rumah Sakit, PLN, Kantor camat, dan lainnya.Tetapi masih ada saja kendala dalam pelayanan jasa publik tersebut. Salah satunya adalah ketidaknyamanan pelanggan dan prosedur pelayanannya 
masih berbelit-belit sehingga bagi masyarakat. Dengan demikian pelanggan tidak merasa puas oleh pelayanan publik yang terbaik adalah pelayanan jasa tersebut. Padahal memberikan kepuasan terhadap sudah ada Undang-undang Pelayanan Publik, standar pelayanan ini setidaktidaknya berisi tentang: dasar hukum, persyaratan, prosedur pelayanan, waktu penyelesaian, biaya pelayanan, pengawasan intern, penanganan pengaduan, saran dan masukan, dan jaminan pelayanan. Namun hal tersebut masih saja tidak berpengaruh pada pelayanan jasa publik yang baik.

Seharusnya para pemberi layanan tersebut melihat pada Undang-undang pelayanan publik tersebut merasa puas dan nyaman.

Pelayanan publik adalah suatu tindakkan pemberian dan jasa kepada masyarakat oleh pemerintah dalam rangka tanggung jawabnya kepada publik, baik diberikan secara langsung maupun melalui kemitraan dengan swasta dan masyarakat, berdasarkan jenis dan intensitas kebutuhan masyarakat. Pelayanan publik ini dapat dilihat sehari-hari di bidang administrasi, keamanan, kesehatan, pendidikan, telekomunikasi dan sebagainya. Tujuan pelayanan publik adalah publik, kalau perlu melebihi harapan publik.

Menurut Hamidi (2006) pelayanan publik yang diselenggarakan oleh pemerintah, secara umum dapat dikelompokkan menjadi tiga macam yaitu : pertama, pelayanan primer adalah pelayanan yang paling mendasar atau dapat disebut juga pelayanan minimum, seperti pelayanan kewarganegaraan, pelayanan kesehatan, pelayanan pendidikan, dan pelayanan ekonomi. Kedua, pelayanan sekunder yaitu pelayanan pendukung namun bersifat spesifik.Dan ketiga, pelayanan tersier yaitu pelayanan yang berhubungan secara tidak langsung kepada publik.

Kotler menyatakan bahwa kepuasan adalah tingkat perasaan seseorang setelah membandingkan kinerja atau hasil yang ia rasakan dan dibandingkan dengan harapannya, sedangkan Wilkie mendefinisikan kepuasan pelanggan sebagai suatu tanggapan emosional pada evaluasi terhadap pengalaman konsumsi suatu produk atau jasa (Tjiptono, 1997). menyediakan barang jasa yang terbaik 
Sejalan dengan hal terdebut menerima keluhan pelanggan diatas, maka untuk memenuhi (masyarakat).

keinginan masyarakat (pelanggan),

Ketiga, Keamanan, dalam arti Menteri Negara Pendayagunaan bahwa proses serta hasil pelayanan Aparatur Negara (MENPAN) dalam umum dapat memberikan keamanan keputusannya Nomor: 81/1995 menegaskan bahwa pelayanan yang berkualitas hendaknya sesuai dengan sendi-sendi sebagai berikut:

Pertama, Kesederhanaan, dalam arti bahwa prosedur atau tata cara pelayanan diselenggarakan secara mudah, lancar, cepat dan tidak berbelit-belit serta mudah difahami dan dilaksdanakan.

Kedua, Kejelasan dan kepastian, menyangkut prosedur atau tata cara pelayanan umum, Persyaratan pelayanan umum, baik teknis maupun administrative, Unit kerja atau pejabat yang bertanggung jawab dalam memberikan pelayanan umum, Rincian biaya atau tarif pelayanan umum dan tata cara pembayarannya, Jadwal waktu penyelesaian pelayanan umum, Hak dan kewajiban baik dari pemberi maupun penerima pelayanan umum berdasarkan bukti-bukti penerimaan permohonan atau kelengkapannya, sebagai alat untuk memastikan pemrosesan pelayanan umum yang dan kenyamanan serta dapat memberikan kepastian hukum. Keempat, Keterbukaan, dalam arti bahwa prosedur atau tata cara, persyaratan, satuan kerja atau pejabat penanggung jawab pemberi pelayanan umum, waktu penyelesaian dan rincian biaya atau tarif dan halhal lain yang yang berkaitan dengan proses pelayanan umum wajib diinformasikan secara terbuka agar mudah diketahui dan difahami oleh masyarakat, baik diminta maupun tidak diminta.

Kelima, Efisien, meliputi Persyaratan pelayanan umum hanya dibatasi pada hal-hal yang berkaitan langsung dengan pencapaian sasaran pelayanan dengan tetap memperhatikan keterpaduan antara persyaratan dengan produk pelayanan umum yang diberikan, Dicegah adanya pengulangan pemenuhan kelengkapan persyaratan, dalam hal proses pelayanannya mempersyaratkan kelengkapan 
persyaratan dari satuan kerja atau instansi pemerintah lain yang terkait.

Keenam, Ekonomis, dalam arti pengenaan biaya pelayanan umum harus ditetapkan secara wajar dengan memperhatikan nilai barang atau jasa pelayanan umum dengan tidak menuntut biaya yang tinggi diluar kewajaran, Kondisi dan kemampuan pelanggan (masyarakat) untuk membayar secara umum berdasar ketentuan peraturan perundangundangan yang berlaku. Ketujuh, Keadilan yang merata dalam arti cakupan atau jangkauan pelayanan umum harus diusahakan seluas mungkin dengan distribusi yang merata dan diberlakukan secara adil.

Kedelapan, Ketepatan waktu, dalam arti pelaksanaan pelayanan umum dapat diselesaikan dalam kurun waktu yang telah ditentukan.Kompetensi pelayanan prima yang diberikan oleh aparatur pemerintahan kepada masyarakat, selain dapat dilihat dalam keputusan Menpan nomor 81/1993, juga dipertegas dalam instruksi Presiden nomor 1/1995 tentang peningkatan kualitas aparatur pemerintah kepada masyarakat.
Berdasarkan prinsip pelayanan publik dan masih banyaknya persoalan dalam pelayanan publik yang terjadi di Kota Malang karena masih banyak masyarakat yang merasa belum mendapatkan pelayanan yang baik dari pelayanan publik membuat peneliti tertarik untuk penelitian mengenai hal ini.

\section{METODE PENELITIAN}

Lokasi penelitian ini adalah Kecamatan Kedung kandang Kota Malang dan objek adalah masyarakat yang menggunakan pelayanan jasa publik di kecamatan tersebut. Jenis penelitian yang digunakan adalah menggunakan pendekatan deskriptif analitis (analytical descriptive approach) secara kualitatif dengan menggunakan metode survei. Pada penelitian ini prosedur penarikan sampel menggunakan metode "Accidential Sampling” adalah merupakan data yang langsung di berikan dan diperoleh dari responden yang saat itu atau sedang mengurus pelayanan di lima dinas tersebut.

Pada penelitian ini teknik analisa datanya dilakukan dengan menggunakan tabulasi data dan nilai Indeks Kepuasan Masyarakat (IKM) 
yang dihitung menggunakan nilai rata-rata tertimbang masing-masing unsur pelayanan.

\section{PEMBAHASAN}

Analisis Tabulasi digunakan untuk mengetahui sejauh mana kepuasan pelayanan publik yang ada di Kecamatan Kedungkandang Kota Malang. Indikator yang pertama yang akan dijelaskan adalah tentang prosedur pelayanan. Indikator ini terdiri dari 2 item yaitu tingkat kepuasan mengenai kesederhanaan akan prosedur pelayanan dan tingkat kepuasan mengenai kejelasan alur dalam prosedur pelayanan. Alasan penggunaan 2 item tersebut untuk menjadi tolak ukur yang lebih merinci tentang penilaian tingkat kepuasan pelayanan publik responden. indikator prosedur pelayanan dalam penelitian ini terdiri dari 2 sub indikator untuk pertanyaan yaitu tingkat kepuasan mengenai kesederhanaan prosedur pelayanan untuk pertanyaan nomor 1 , dan tingkat kepuasan mengenai kejelasan alur dalam prosedur pelayanan untuk pertanyaan nomor 2 .

Berdasarkan data hasil penelitian dan setelah dilakukan tabulasi data maka diperoleh kenyataan bahwa mayoritas responden menyatakan cukup puas terhadap indikator prosedur pelayanan yang terdiri dari 2 sub indikator dimana 70-79 persen responden menyatakan demikian. Hanya sebagian kecil (10-13) persen yang menyatakan kurang puas, tidak puas, sangat tidak puas, dan sangat puas.

Berdasarkan survey yang dilakukan dapat diketahui bahwa 37 responden atau sebesar $62 \%$ menyatakan cukup puas terhadap kesederhanaan prosedur pelayanan dan menduduki urutan pertama, adapun urutan yang kedua adalah sebanyak 16 responden atau sebesar $27 \%$ yang menyatakan kurang puas terhadap kesederhanaan prosedur pelayanan sedangkan urutan yang ketiga adalah 5 responden atau sebesar $8 \%$ yang menyatakan tidak puas tehadap kesederhanaan prosedur pelayanan dan urutan keempat adalah 2 responden atau sebesar 3\% menyatakan sangat puas terhadap kesederhanaan prosedur pelayanan sedangkan untuk responden yang menyatakan sangat tidak puas terhadap kesederhanaan prosedur pelayanan tidak ada atau $0 \%$. 
Selain itu, mengenai kejelasan alur dalam prosedur pelayanan dapat diketahui bahwa sebanyak 36 responden atau sebesar 59\% menyatakan cukup puas terhadap kejelasan alur dalam prosedur pelayanan, adapun urutan kedua sebanyak 19 responden atau sebesar $32 \%$ menyatakan kurang puas terhadap kejelasan alur dalam prosedur pelayanan sedangkan urutan yang ketiga sebanyak 4 responden atau sebesar $7 \%$ menyatakan tidak puas terhadap kejelasan alur dalam prosedur pelayanan dan diurutan keempat sebanyak 1 responden atau sebesar $2 \%$ menyatakan sangat tidak puas terhadap kejelasan alur dalam prosedur pelayanan serta yang terakhir sebanyak 0 atau sebesar $0 \%$ menyatakan sangat puas terhadap kejelasan alur dalam prosedur pelayanan.

Kedua kriteria yaitu kesederhanaan prosedur pelayanan dan kejelasan alur dalam prosedur pelayanan dinilai oleh sebagian besar responden yang menyatakan cukup puas, hal ini dikarenakan adanya informasi yang jelas dari pihak pelayanan publik itu sendiri baik berupa papan pengumuman maupun informasi yang lain.

Selanjutnya apabila keseluruhan sub indikator di atas dilihat berdasarkan bobot skor yang telah diperoleh maka akan di peroleh bobot rata-rata sebesar 427 , sehingga nilai skor untuk prosedur pelayanan di Kecamatan Kedungkandang Kota Malang adalah sebesar 25,62 sehingga dapat dikategorikan dalam tingkat kepuasan masyarakat di Kecamatan Kedungkandang Kota Malang adalah cukup puas.

Pembahasan berikutnya yaitu indikator persyaratan pelayanan, Indikator persyaratan pelayanan dalam penelitian ini terdiri dari 2 sub indikator untuk 2 pertanyaan yaitu mengenai kejelasan persyaratan pelayanan untuk pertanyaan nomor 1 dan mengenai kemudahan dalam mengurus dan memenuhi persyaratan pelayanan untuk pertanyaan nomor 2 .

Berdasarkan survey yang dilakukan dapat diketahui bahwa sebanyak 37 responden atau sebesar $62 \%$ menyatakan cukup puas terhadap kejelasan persyaratan pelayanan, sedangkan 17 responden atau sebesar $28 \%$ menyatakan kurang puas terhadap kejelasan persyaratan 
pelayanan serta 5 responden atau sebesar $8 \%$ menyatakan tidak puas terhadap kejelasan persyaratan pelayanan sedangkan sebanyak 1 responden atau sebesar $2 \%$ menyatakan sangat puas teerhadap kejelasan persyaratan pelayanan dan sangat tidak puas terhadap kejelasan persyaratan pelayanan tidak ada responden atau yang menyatakan $0 \%$.

Adapun mengenai kemudahan dalam mengurus dan memenuhi persyaratan pelayanan, dapat diketahui bahwa sebanyak 38 responden atau sebesar $63 \%$ menyatakan cukup puas mengenai kemudahan dalam mengurus dan memenuhi persyaratan pelayanan sedangkan 18 responden lainnya atau sebesar $30 \%$ menyatakan kurang puas mengenai kemudahan dalam mengurus dan memenuhi persyaratan pelayanan serta 3 responden atau sebesar 5\% menyatakan tidak puas mengenai kemudahan dalam mengurus dan memenuhi persyaratan pelayanan dan sisanya 1 responden atau sebesar $2 \%$ menyatakan sangat tidak puas mengenai kemudahan dalam mengurus dan memenuhi persyaratan pelayanan sedangakan untuk sangat puas tidak ada responden yang menyatakan itu atau sebesar $0 \%$.

Hasil tabulasi dari kedua sub indikator menghasilkan bobot ratarata sebesar 427 dengan nilai skor sebesar 25,62 sehingga secara keseluruhan indikator persyaratan pelayanan dapat dikatakan bahwa tingkat kepuasan masyarakat di Kecamatan Kedungkandang Kota Malang akan persyaratan pelayanan adalah cukup puas.

Pembahasan berikutnya yaitu indikator kejelasan dan tanggung jawab petugas pelayanan, Indikator kejelasan dan tanggung jawab petugas pelayanan dalam penelitian ini terdiri dari 2 sub indikator untuk 2 pertanyaan yaitu mengenai kemudahan petugas pelayanan untuk ditemui untuk pertanyaan nomor 5 dan mengenai wewenang tugas dan tanggungjawab petugas untuk pertanyaan nomor 6 .

Berdasarkan survey yang dilakukan dapat diketahui bahwa sebanyak 34 responden atau sebesar $56 \%$ menyatakan cukup puas mengenai kemudahan petugas pelayanan untuk ditemui dan di urutan kedua sebanyak 19 responden atau sebesar $32 \%$ menyatakan kurang 
puas mengenai kemudahan petugas pelayanan untuk ditemui dan di tingkat ketiga dan ke empat sebanyak 3 responden atau sebesar 5\% menyatakan tidak puas dan sangat tidak puas mengenai kemudahan petugas pelayanan untuk ditemui sedangkan untuk pilihan sangat puas sebanyak 1 responden atau sebesar $2 \%$ memilihnya.

Adapun mengenai wewenang tugas dan tanggungjawab petugas, dapat diketahui bahwa sebanyak 37 responden atau sebesar $62 \%$ menyatakan cukup puas mengenai wewenang tugas dan tanggungjawab petugas dan sebanyak 15 responden menyatakan kurang puas mengenai wewenang tugas dan tanggungjawab petugas. Sedangkan sebanyak 4 responden menyatakan tidak puas mengenai wewenang tugas dan tanggungjawab petugas dan sisanya yang menyatakan sangat puas dan sangat tidak puas sebanyak 2 responden atau sebesar 3\%.

Bila secara keseluruhan apabila kedua sub indikator dirata-rata, maka akan diperoleh bobot sebesar 420 dengan nilai skor sebesar 25,2. Berdasarkan nilai skor yang ada dapat dikatakan bahwa tingkat kepuasan masyarakat di Kecamatan Kedungkandang Kota Malang akan kejelasan dan tanggungjawab petugas pelayanan adalah cukup puas.

Pembahasan berikutnya yaitu indikator kedisplinan dan kecepatan pelayanan, indikator kedisplinan dan kecepatan pelayanan dalam penelitian ini terdiri dari 2 sub indikator yaitu mengenai ketepatan waktu petugas dalam menyelesaikan suatu pelayanan untuk pertanyaan nomor 7 dan mengenai keberadaan petugas pada saat jam kerja dan ketepatan akan janji petugas pelayanan untuk pertanyaan nomor 8 .

Berdasarkan hasil survey dapat diketahui bahwa sebanyak 31 responden atau sebesar 52\% menyatakan cukup puas mengenai ketepatan waktu petugas dalam menyelesaikan suatu pelayanan dan sebanyak 18 responden atau sebesar $30 \%$ menyatakan kurang puas mengenai ketepatan waktu petugas dalam menyelesaikan suatu pelayanan dan sebanyak 9 responden atau sebesar $15 \%$ menyatakan tidak puas mengenai ketepatan waktu petugas dalam menyelesaikan suatu pelayanan dan sisanya sebanyak 2 responden atau sebesar 3\% menyatakan sangat 
tidak puas mengenai ketepatan petugas dalam menyelesaikan suatu pelayanan dan untuk jawaban sangat puas tidak ada responden atau sebesar $0 \%$.

\section{Pembahasan berikutnya} mengenai keberadaan petugas saat jam kerja dan ketepatan akan janji petugas pelayanan. Hasil survey menunjukkan bahwa sebanyak 33 responden atau sebesar 55\% menyatakan cukup puas mengenai keberadaan petugas saat jam kerja dan ketepatan akan janji petugas pelayanan dan sebanyak 15 responden atau sebesar $25 \%$ menyatakan kurang puas mengenai keberadaan petugas saat jam kerja dan ketepatan akan janji petugas pelayanan sedangkan sebanyak 10 responden atau sebesar $17 \%$ menyatakan tidak puas mengenai keberadaan petugas saat jam kerja dan ketepatan akan janji petugas pelayanan dan sisanya sebanyak 2 responden atau sebesar $3 \%$ menyatakan sangat tidak puas mengenai keberadaan petugas saat jam kerja dan ketepatan akan janji petugas pelayanan sedangkan untuk pilihan jawaban sangat puas tidak ada responden yang memilih atau sebesar $0 \%$.
Selanjutnya apabila bobot nilai keseluruhan sub indikator dirata-rata, maka akan diperoleh bobot sebesar 401 dan skor yang diperoleh sebesar 24,06. Berdasarkan nilai skor yang ada dapat dikatakan bahwa tingkat kepuasan masyarakat di Kecamatan Kedungkandang Kota Malang akan kedisplinan dan kecepatan pelayanan adalah cukup puas.

Indikator yang berikutnya yaitu indikator kemampuan petugas pelayanan dalam penelitian ini terdiri dari 2 sub indikator atau 2 pertanyaan yaitu mengenai kemampuan petugas untuk member solusi yang ada untuk pertanyaan nomor 9 dan mengenai keahlian dan keterampilan petugas pelayanan dalam memberikan pelayanan untuk pertanyaan nomor 10.

Berdasarkan hasil survey dapat diketahui sebanyak 34 responden atau sebesar 56\% menyatakan cukup puas mengenai kemampuan petugas untuk memberi solusi dan sebanyak 19 responden atau sebesar 32\% menyatakan kurang puas mengenai kemampuan petugas untuk memberi solusi sedangkan sebanyak 6 responden atau sebesar $10 \%$ menyatakan tidak puas mengenai 
kemampuan petugas untuk memberi solusi dan sisanya sebanyak 1 responden atau sebesar $2 \%$ menyatakan sangat puas mengenai kemampuan petugas untuk memberi solusi sedangkan untuk pilihan jawaban sangat tidak puas tidak ada responden yang memilih atau sebesar $0 \%$.

Adapun mengenai keahlian dan keterampilan petugas dalam memberikan pelayanan, dapat diketahui bahwa sebanyak 36 responden atau sebesar $60 \%$ menyatakan cukup puas mengenai keahlian dan keterampilan petugas dalam memberikan pelayanan dan sebanyak 22 responden atau sebesar $37 \%$ menyatakan kurang puas mengenai keahlian dan keterampilan petugas dalam memberikan pelayanan dan sisanya sebanyak 2 responden atau sebesar 3\% menyatakan tidak puas mengenai keahlian dan keterampilan petugas dalam memberikan pelayanan sedangkan untuk pilihan jawaban sangat puas dan sangat tidak puas tidak ada responden yang memilih atau sebesar $0 \%$.

Dari kedua sub indikiator tersebut, secara keseluruhan untuk indikator kemampuan petugas pelayanan mempunyai bobot nilai 424 dengan nilai sebesar 25,44 yang berarti tingkat kepuasan masyarakat di Kecamatan Kedungkandang Kota Malang akan indikator kemampuan petugas pelayanan adalah cukup puas.

Indikator yang selanjutnya yaitu indikator keadilan mendapatkan pelayanan. Indikator keadilan mendapatkan pelayanan dalam penelitian ini terdiri dari 2 sub indikator dalam 2 pertanyaan yaitu mengenai keadilan petugas tidak membedakan status atau golongan dalam memberikan pelayanan untuk pertanyaan nomor 11 dan mengenai kemerataan jangkauan atau cakupan dalam memberikan pelayanan untuk petanyaan nomor 12 .

Berdasarkan hasil survey dapat diketahui bahwa sebanyak 27 responden atau sebesar $45 \%$ menyatakan cukup puas mengenai keadilan petugas tidak membedakan status atau golongan dalam mendapatkan pelayanan dan sebanyak 18 responden atau sebesar $30 \%$ menyatakan kurang puas mengenai keadilan petugas tidak membedakan status atau golongan dalam mendapatkan pelayanan serta 
sebanyak 7 responden atau sebesar $12 \%$ menyatakan tidak puas mengenai keadilan petugas tidak membedakan status atau golongan dalam memberikan pelayanan sedangkan sisanya sebanyak 6 responden atau sebesar 10\% menyatakan sangat tidak puas mengenai keadilan petugas tidak membedakan status atau golongan dalam memberikan pelayanan dan sebanyak 2 responden atau sebesar $3 \%$ menyatakan sangat puas mengenai keadilan petugas tidak membedakan status atau golongan dalam memberikan pelayanan.

Adapun mengenai kemerataan jangkauan atau cakupan dalam memberikan pelayanan, dapat diketahui bahwa sebanyak 32 responden atau sebesar 53\% menyatakan cukup puas mengenai kemerataan jangkuan atau cakupan dalam memberikan pelayanan dan sebanyak 16 responden atau sebesar $27 \%$ menyatakan kurang puas mengenai kemerataan jangkauan atau cakupan dalam memberikan pelayanan dan sisanya sebanyak 12 responden atau sebesar 20\% menyatakan tidak puas mengenai kemerataan jangkauan atau cakupan dalam memberikan pelayanan sedangkan untuk pilihan jawaban sangat tidak puas dan sangat puas tidak ada responden yang memilih atau sebesar $0 \%$.

Bila dilihat berdasarkan indikator penilaian, apabila kedua sub indikator tersebut dirata-rata akan diperoleh bobot nilai sebesar 426 sehingga nilai skor yang diperoleh 25,56 yang artinya masyarakat di Kecamatan Kedungkandang Kota Malang tingkat kepuasannya akan indikator keadilan mendapatkan pelayanan adalah cukup puas.

Indikator selanjutnya yaitu indikator kesopanan dan keramahan petugas pelayanan. Indikator kesopanan dan keramahan petugas dalam penelitian ini terdiri dari $2 \mathrm{sub}$ indikator dalam 2 pertanyaan yaitu mengenai kesopanan dan penghormatan petugas dalam memberikan pelayanan untuk pertanyaan nomor 13 dan mengenai keramahan petugas dalam memberikan pelayanan untuk pertanyaan nomor 14 .

Kesopanan dan keramahan petugas adalah bentuk penghargaan mereka terhadap masyarakat. Hal semacam ini dapat dirasakan sekali 
oleh masyarakat, bila mereka dialayani dengan baik dan sopan serta menghargai masyarakat maka tingkat kepuasan masyarakat di Kecamatan Kedungkandang Kota Malang tentunya akan meningkat.

Berdasarkan hasil survey dapat diketahui bahwa sebanyak 42 responden atau sebesar $70 \%$ menyatakan cukup puas mengenai kesopanan dan penghormatan petugas dalam memberikan pelayanan dan sebanyak 15 responden atau sebesar $25 \%$ menyatakan kurang puas mengenai kesopanan dan penghormatan petugas dalam memberikan pelayanan sedangkan sebanyak 2 responden atau sebesar $3 \%$ menyatakan tidak puas mengenai kesopanan dan penghormatan petugas dalam memberikan pelayanan dan sisanya sebanyak 1 responden atau sebesar $2 \%$ menyatakan sangat tidak puas mengenai kesopanan dan pengormatan petugas dalam memberikan pelayanan sedangkan untuk pilihan jawaban sangat puas tidak ada responden yang memilih atau sebesar $0 \%$.

Adapun mengenai keramahan petugas dalam memberikan pelayanan, dapat diketahui bahwa sebanyak 43 responden atau sebesar $71 \%$ menyatakan cukup puas mengenai keramahan petugas dalam memberikan pelayanan dan sebanyak 15 responden atau sebesar $25 \%$ menyatakan kurang puas mengenai keramahan petugas dalam memberikan pelayanan sedangkan sisanya yang memilih jawaban tidak puas dan sangat puas sebanyak 1 responden atau sebesar $2 \%$ sedangkan sisanya yang memilih sangat tidak puas tidak ada responde atau sebesar $0 \%$.

Hasil dari kedua sub indikator maka jika bobot nilai dirata-rata akan diperoleh bobot sebesar 442, sehingga diperoleh nlai skor 26,52 dan dapat dikatakan bahwa tingkat kepuasan masyarakat di Kecamatan Kedungkandang Kota Malang akan indikator kesopanan dan keramahan petugas pelayanan adalah cukup puas. Indikator selanjutnya dalam pembahasan ini yaitu indikator kewajaran dan kepastian biaya pelayanan dalam penelitian ini terdiri dari 2 sub indikator dalam 2 pertanyaan yaitu mengenai keterjangkauan biaya yang dikenakan oleh petugas dalam memberikan pelayanan untuk pertanyaan nomor 15 
dan mengenai biaya yang dikenakan sudah sesuai dengan standar biaya umum untuk pertanyaan nomor 16 .

Berdasarkan hasil survey dapat diketahui bahwa sebanyak 36 responden atau sebesar $60 \%$ menyatakan cukup puas mengenai keterjangkauan biaya yang dikenakan oleh petugas dalam memberikan pelayanan dan sebanyak 14 responden atau sebesar $23 \%$ menyatakan kurang puas mengenai keterjangkauan biaya yang dikenakan oleh petugas dalam memberikan pelayanan sedangkan sebanyak 7 responden atau sebesar $12 \%$ menyatakan sangat tidak puas mengenai keterjangkauan biaya yang dikenakan oleh petugas dalam memberikan pelayanan dan sisanya sebanyak 3 responden atau sebesar $2 \%$ menyatakan tidak puas mengenai keterjangkauan biaya yang dikenakan oleh petugas dalam memberikan pelayanan sedangkan untuk pilihan jawaban sangat puas tidak ada responden atau sebesar $0 \%$.

Adapun mengenai biaya yang dikenakan sudah sesuai dengan standar biaya umum, dapat diketahui bahwa sebanyak 38 responden atau sebesar $63 \%$ menyatakan cukup puas mengenai biaya yang dikenakan sudah sesuai dengan standar biaya umum dan sebanyak 12 responden atau sebesar $20 \%$ menyatakan kurang puas mengenai biaya yang dikenakan sudah sesuai dengan standar biaya umum sedangkan di tingkat ketiga sebanyak 6 responden atau sebesar $10 \%$ menyatakan sangat tidak puas mengenai biaya yang dikenakan sudah sesuai dengan standar biaya umum dan sisanya sebanyak 3 responden atau sebesar menyatakan tidak puas mengenai biaya yang dikenakan sudah sesuai dengan standar biaya umum sedangkan untuk pilihan jawaban sangat puas sebanyak 1 responden atau sebesar 2\% memilihnya.

Hasil yang diperoleh dari ratarata kedua sub indikator menunjukan angka 420 atau sehingga skor nilai yang diperoleh sebesar 25,2 yang dapat dikatakan tingkat kepuasan masyarakat di Kecamatan Kedungkandang Kota Malang akan indikator kewajaran dan kepastian biaya pelayanan adalah cukup puas.

Indikator selanjutnya yaitu indikator kenyamanan lingkungan. Indikator kenyamanan lingkungan dalam penelitian ini terdiri dari 4 sub indikator dalam 4 pertanyaan yaitu 
mengenai penampilan gedung sebanyak 6 responden atau sebesar pelayanan untuk pertanyaan nomor $10 \%$ menyatakan kurang puas 17, mengenai penampilan petugas mengenai penampilan petugas pelayanan untuk pertanyaan nomor pelayanan sedangkan di tigkat ketiga 18, mengenai ketersediaan fasilitas pendukung pelayanan untuk pertanyaan nomor 19 dan mengenai kebersihan dan kerapian lingkungan tempat pelayanan untuk pertanyaan nomor 20.

Berdasarkan hasil survey dapat diketahui bahwa sebanyak 49 responden atau sebesar $82 \%$ menyatakan cukup puas mengenai penampilan gedung pelayanan dan di tingkat kedua sebanyak 6 responden atau sebesar $8 \%$ menyatakan kurang puas mengenai penampilan gedung pelayanan sedangkan sisanya sebanyak 5 responden atau sebesar $8 \%$ menyatakan sangat puas mengenai penampilan gedung pelayanan dan untuk pilihan jawaban tidak puas dan sangat tidak puas tidak ada responden yang memilih atau sebesar $0 \%$.

Adapun mengenai penampilan petugas pelayanan, dapat diketahui bahwa sebanyak 52 responden atau sebesar $86 \%$ menyatakan cukup puas mengenai penampilan petugas dan keempat sebanyak 1 responden atau sebesar $2 \%$ menyatakan tidak puas dan sangat puas mengenai penampilan petugas pelayanan dan untuk pilihan jawaban sangat tidak puas tidak ada responden yang memilih atau sebesar $0 \%$.

Berkaitan dengan ketersediaan fasilitas pendukung pelayanan, dapat diketahui bahwa sebanyak 44 responden atau sebesar $73 \%$ menyatakan cukup puas mengenai ketersediaan fasilitas pendukung pelayanan dan di tingkat kedua sebanyak 13 responden atau sebesar $22 \%$ menyatakan kurang puas mengenai ketersediaan fasilitas pendukung sedangkan di tingkat ketiga sebanyak 2 responden atau sebesar 3\% menyatakan tidak puas mengenai fasilitas pendukung dan sisanya sebanyak 1 responden atau sebesar $2 \%$ menyatakan sangat puas mengenai fasilitas pendukung dan untuk pilihan jawaban sangat tidak puas tidak ada responden yang memilih atau sebesar $0 \%$.

pelayanan dan di tingkat kedua 
Berkaitan dengan kebersihan dan kerapian lingkungan tempat pelayanan, dapat diketahui bahwa sebanyak 41 responden atau sebesar $68 \%$ menyatakan cukup puas mengenai kebersihan dan kerapian lingkungan tempat pelayanan dan sebanyak 11 responden atau sebesar $18 \%$ menyatakan kurang puas sedangkan sebanyak 4 responden atau sebesar $7 \%$ menyatakan sangat puas mengenai kebersihan dan kerapian lingkungan tempat pelayanan dan sisanya sebanyak 3 responden atau sebesar 3 responden atau sebesar 5\% menyatakan tidak puas mengenai kebersihan dan kerapian linkungan tempat pelayanan sedangkan untuk pilihan jawaban sangat tidak puas sebanyak 1 responden atau sebesar $2 \%$ yang memilih.

Berdasrkan hasil keempat sub indikator tersebut maka bobot nilai dari keempat sub indikator tersebut dirata-rata, maka akan diperoleh bobot sebesar 924 dengan nilai skor sebesar 55,44. Yang dapat dikatakan tingkat kepuasan masyarakat di Kecamatan Kedungkandang Kota Malang akan indikator kenyamanan lingkungan adalah sangat puas.
Indikator selanjutnya yaitu indikator keamanan pelayanan. Indikator keamanan pelayanan dalam peneltian ini terdiri dari 2 sub indikator dalam 2 pertanyaan yaitu mengenai tingkat keamanan lingkungan tempat pelayanan untu pertanyaan nomor 21 dan mengenai tingkat keamanan sarana dan prasarana pelayanan untuk pertanyaan nomor 22.

Berdasarkan hasil survey dapat diketahui bahwa sebanyak 47 responden atau sebesar $78 \%$ menyatakan cukup puas mengenai tingkat keamanan lingkungan tempat pelayanan dan di tingkat kedua sebanyak 10 responden atau sebesar $17 \%$ menyatakan kurang puas mengenai tingkat keamanan lingkungan tempat pelayanan sedangkan di tingkat ketiga sebanyak 2 responden atau sebesar 3\% menyatakan sangat tidak puas mengenai tingkat keamanan lingkungan tempat pelayanan dan sisanya sebanyak 1 responden atau sebesar $2 \%$ menyatakan sangat puas mengenai tingkat keamanan lingkungan tempat pelayanan dan untuk pilihan jawaban sangat tidak 
puas tidak ada responden yang memilih atau sebesar $0 \%$.

Berkaitan dengan tingkat keamanan sarana dan prasarana pelayanan, dapat diketahui bahwa sebanyak 48 responden atau sebesar $80 \%$ menyatakan cukup puas mengenai tingkat keamanan sarana dan prasarana dan di tingkat kedua sebanyak 9 responden atau sebesar $15 \%$ menyatakan kurang puas mengenai tingkat keamanan sarana dan prasarana sedangkan di tingkat ketiga sebanyak 2 responden atau sebesar 3\% menyatakan tidak puas mengenai tingkat keamanan sarana dan prasarana dan sisanya sebanyak 1 responden atau sebesar $2 \%$ menyatakan tidak puas mengenai

tingkat keamanan sarana dan prasarana sedangkan sisanya sebanyak 1 responden atau sebesar $2 \%$ menyatakan sangat tidak puas mengenai tingkat keamanan sarana dan prasarana dan untuk jawaban pilihan sangat puas tidak ada responden yang memilih atau sebesar $0 \%$.

Sehingga apabila bobot nilai dari kedua sub indikator dirata-rata, maka akan diperoleh bobot sebesar 458 dan skor sebesar 27,48 yang dapat dikatakan tingkat kepuasan masyarakat di Kecamatan Kedungkandang Kota Malang akan indikator keamanan pelayanan adalah cukup puas.

\section{Tabel 1. Nilai Rata-rata Unsur dari masing-masing Unit Pelayanan Publik} yang Ada Di Kecamatan Kedungkandang Kota Malang

\begin{tabular}{llccl}
\hline NO & \multicolumn{1}{c}{ Unsur Pelayanan } & $\begin{array}{c}\text { Bobot } \\
\text { rata-rata } \\
\text { unsur }\end{array}$ & $\begin{array}{c}\text { Nilai } \\
\text { rata-rata } \\
\text { unsur }\end{array}$ & Keterangan \\
\hline 1 & Prosedur pelayanan & 427 & 25,62 & Cukup puas \\
2 & Persyaratan pelayanan & 427 & 25,62 & Cukup puas \\
3 & Kejelasan dan tanggungjawab & 420 & 25,2 & Cukup puas \\
4 & Kedisplinan dan kecepatan & 401 & 24,06 & Cukup puas \\
& pelayanan & & & \\
5 & Kemampuan petugas pelayanan & 424 & 25,44 & Cukup puas \\
6 & Keadilan mendapatkan pelayanan & 426 & 25,66 & Cukup puas \\
7 & Kesopanan dan keramahan petugas & 442 & 26,52 & Cukup puas \\
& pelayanan & & & \\
\hline
\end{tabular}




\begin{tabular}{clcrc}
\hline 8 & $\begin{array}{l}\text { Kewajaran dan kepastian biaya } \\
\text { pelayanan }\end{array}$ & 420 & 25,2 & Cukup puas \\
9 & Kenyamanan lingkungan & 924 & 55,44 & Sangat puas \\
10 & Keamanan pelayanan & 458 & 27,48 & Cukup puas \\
\hline
\end{tabular}

Sumber : Data Penelitian Diolah, 2011.

Gambaran hasil penilaian seluruh indikator yang diteliti dalam penelitian ini dapat dilihat pada tabel 1, dari kesepuluh indikator tersebut terdapat Sembilan indikator yang dapat dikatakan tingkat kepuasannya adalah cukup puas, kesembilan indikator tersebut adalah prosedur pelayanan, persyaratan pelayanan, kejelasan dan tanggung jawab petugas pelayanan, kedisplinan dan kecepatan pelayanan, kemampuan petugas pelayanan, keadilan mendapatkan pelayanan, kesopanan dan keramahan petugas pelayanan, kewajaran dan kepastian biaya pelayanan dan keamanan lingkungan. Sementara satu indikator yang menurut tingkat kepuasan responden cukup puas adalah indikator kenyamanan lingkungan.

Setelah menganalisis indikatorindikator kinerja di atas, berikut ini akan dianalisis indeks kepuasan masyarakat (IKM) atas pelayanan publik di Kecamatan Kedungkandang Kota Malang secara keseluruhan. Analisis ini dapat dilakukan dengan cara menghitung nilai indeks dari unit pelayanan kinerja secara keseluruhan, adapun nilai indeks dapat diperoleh dengan cara mengalikan masingmasing nilai rata-rata unsur dengan bobot nilai rata-rata tertimbang lalu dikalikan dengan nilai dasar. Dengan demikian nilai indeks unit pelayanan hasilnya dapat disimpulkan nilai IKM setelah di konversi yaitu nilai indeks $\mathrm{x}$ nilai dasar $(2.645 \times 25)=66.12$. nilai ini masuk dalam kategori mutu tingkat kepuasan $\mathrm{B}$ dan tingkat kepuasan masyarakat Cukup Puas.

Berdasarkan data pada tabel 1 , maka nilai indeks secara keseluruhan diperoleh angka indeks sebesar 66.12. Dengan demikian tingkat kepuasan masyarakat di Kecamatan Kedungkandang Kota Malang dilihat dari seluruh indikator yang ada dipelayanan publik menyatakan cukup puas.

\section{PENUTUP}

Berdasarkan hasil analisis dapat diketahui tingkat kepuasan masyarakat terhadap pelayanan publik di Kecamatan Kedungkandang 
Kota Malang adalah cukup puas. Hal ini dapat dikatakan bahwa tingkat kepuasan masyarakat terhadap pelayanan publik di Kecamatan Kedungkandang Kota Malang yang mencakup dalam 9 indikator hanya masih cukup puas, 9 indikatorindikator tersebut mencakup: prosedur pelayanan, persyaratan pelayanan, kejelasan dan tanggungjawab petugas pelayanan, kedisplinan dan kecepatan pelayanan, kemampuan petugas pelayanan, keadilan mendapatkan pelayanan, kesopanan dan keramahan petugas pelayanan, kewajaran dan kepastian biaya pelayanan, dan keamanan pelayanan.

Sepuluh (10) Indikator tersebut terbagi menjadi 9 indikator terendah dan 1 indikator tertinggi, 9 indikator terendah yaitu Indikator Kedisplinan dan Kecepatan Pelayanan, Indikator Kejelasan dan Tanggungjawab Petugas Pelayanan, Indikator Kewajaran dan Kepastian Biaya Pelayanan, Indikator Kemampuan Petugas Pelayanan, Indikator Prosedur Pelayanan, Indikator Persyaratan Pelayanan, Indikator Kesopanan Dan Keramahan Petugas pelayanan, Indikator Keadilan
Mendapaatkan Pelayanan dan Indikator Keamanan Pelayanan. Sedangkan untuk 1 Indikator tertinggi yaitu Indikator Kenyamanan Lingkungan.

\section{DAFTAR PUSATAKA}

Arikunto, S. 2006. Prosedur penelitian: Suatu Pendekatan Praktik Edisi Revisi. Jakarta: Rineka Cipta.

Azhari. 2008. Analisis Kepuasan Masyarakt Terhadap Pelayanan Publik Dalam Menuju Agropolitan di Kabupaten Malang. Malang: UMM press Keputusan Menteri Pendayaagunaan aparatur Negara (MenPan) nomor 63/7/2003. prisip-prinsip pelayanan publik.

Keputusan Menteri Pendayagunaan aparatur Negara (Menpan) nomor 81/1995. sendi-sendi pelayanan yang berkualitas.

Keputusan Menteri nomor 81/1993. Aspek-aspek Yang Mempengaruhi Pelayanan Yang Tepat Sasaran.

Sedarmayanti. 2003. Good governance. Jakarta: Raja Grafindo Persada

Santosa, Panji. 2008. Administrasi Publik (Teori dan Aplikasi Good Governance). Bandung: PT Refika Aditama.

Sedarmayanti. 2004. Good Governance (Kepemerintahan 
yang baik) Bagian kedua membangun sistem menejemen kinerja guna menigkatkan produktivitas menuju governance (kepemerintahan nyang baik). Bandung: Mandar Maju.

Ulum, Ihyaul. 2005. Akuntansi Sektor Publik. Malang: Umm press. 